\title{
DETERMINATION OF SUITABLE CHEMICAL EXTRACTION METHODS FOR AVAILABLE IRON CONTENT OF THE SOILS FROM EDIRNE PROVINCE IN TURKEY
}

\section{ADILOGLU A.}

\section{ABSTRACT}

The aim of this research was to determine the available iron $(\mathrm{Fe})$ content of the soils of Edirne Province and the most suitable chemical extraction method. Eight chemical extraction methods $(0.005 \mathrm{M}$ DTPA $+0.01 \mathrm{M}$ $\mathrm{CaCl}_{2}+0.1 \mathrm{M}$ TEA; $0.05 \mathrm{M} \mathrm{HCl}+0.012 \mathrm{M} \mathrm{H}_{2} \mathrm{SO}_{4} ; 1 \mathrm{M} \mathrm{NH}_{4} \mathrm{OAc}(\mathrm{pH}: 4.8) ; 0.01 \mathrm{M}$ EDTA + $1 \mathrm{M} \mathrm{NH}_{4} \mathrm{OAc}$; $1 \mathrm{M} \mathrm{MgCl}_{2} ; 0.01 \mathrm{M}$ EDTA + $1 \mathrm{M}\left(\mathrm{NH}_{4}\right)_{2} \mathrm{CO}_{3} ; 0.005 \mathrm{M} \mathrm{DTPA}+1 \mathrm{M} \mathrm{NH}_{4} \mathrm{HCO}_{3}$ and $0.001 \mathrm{M}$ EDDHA methods) and six biological indices (dry matter yield, Fe concentration, Fe uptake, relative dry matter yield, relative Fe concentration, relative Fe uptake) were compared. Biological indices were determined with Barley (Hordeum vulgare L.) grown under greenhouse conditions. At the end of the experiment, the highest correlation coefficients $(r)$ were determined to be between the $0.005 \mathrm{M} \mathrm{DTPA}+0.01 \mathrm{M} \mathrm{CaCl}_{2}+0.1 \mathrm{M}$ TEA method and the biological indices and between the $0.005 \mathrm{M} \mathrm{DTPA}+1 \mathrm{M} \mathrm{NH}_{4} \mathrm{HCO}_{3}$ method and the biological indices. The correlation coefficients $(r)$ for the $0.005 \mathrm{M} \mathrm{DTPA}+0.01 \mathrm{M} \mathrm{CaCl}_{2}+0.1 \mathrm{M}$ TEA method were $\mathrm{r}=0.621^{* *} ; \mathrm{r}=0.823^{* *} ; \mathrm{r}=0.810^{* *} ; \mathrm{r}=0.433^{* *} ; \mathrm{r}=0.558^{* *}$ and $\mathrm{r}=0.640^{* *}$ and for the 0.005 M DTPA $+1 \mathrm{M} \mathrm{NH}_{4} \mathrm{HCO}_{3}$ method $\mathrm{r}=0.618^{* *} ; \mathrm{r}=0.520^{* *} ; \mathrm{r}=0.679^{* *} ; \mathrm{r}=0.521^{* *} ; \mathrm{r}=0.492^{* *}$ and $\mathrm{r}=0.641^{* *},\left({ }^{* *}: \mathrm{p}<0.01\right)$ respectively. These extraction methods, among all the methods tested were suggested for the determination of available Fe content of Edirne Province soils.

KEY WORDS: Fe, extraction methods, barley, biological indice 


\section{INTRODUCTION}

Although required in very small amounts iron $(\mathrm{Fe})$ is an essential nutrient and plays a major role in plant growth and development. The trend to more intensive crop production with higher yields and heavier use of nitrogen $(\mathrm{N})$, phosphorus $(\mathrm{P})$ and potassium $(\mathrm{K})$ fertilizers increases the need for $\mathrm{Fe}$ and other trace elements in agriculture. Soil analyses are helpful in determining whether a soil can supply adequate amounts of Fe for optimal growth.

$\mathrm{Fe}$ deficiency is one of the most common trace element problems in the world nowadays. Fe deficiency is frequent in high $\mathrm{pH}$, high lime, low organic matter content and sandy soils. ([19]). Available $\mathrm{Fe}$ is inadequate in about $26.87 \%$ of turkey's soils ([9]).

Despite the fact that several Fe extraction methods have been developed none of them was suitable to be a standard method ([16]).

Lindsay and Norvell ([18]) and Norvell ([23]) suggested DTPA (pH: 7.3) method for the determination of available Fe content with regards to neutral and alkaline soils.

The 0.001 M EDDHA method was suggested for the determination of available Fe content in the USA, because this method has produced the highest correlation with biological indices ([13]).

Hatipoglu ([12]) has determined correlation coefficients (r) between eleven extraction methods and biological indices to find out about the available $\mathrm{Fe}$ content of the soils from Central South Anatolia. The highest correlation coefficient (r) determined was between $0.001 \mathrm{M}$ EDDHA method and biological indices.

Fe deficiency is a major plant nutrition problem in Edirne region ([9]). In this research, suitable method for the determination of available Fe content of the soils of this region was investigated.

\section{MATERIALS AND METHODS}

Soil samples were taken at $0-20 \mathrm{~cm}$ depth from 25 different cultivated soils in Edirne ([15]). Soil $\mathrm{pH}$ ([32]), lime ([17]), CEC ([31]) and texture ([10]) were determined for each sample.

Some physical and chemical properties of the soil samples are given in Table 1 . The $\mathrm{pH}$ values of soil samples ranged from 6.29 to $7.94 ; \mathrm{CaCO}_{3}$ contents were between $0.00 \%$ and $15.10 \%$; CEC values were between 16.44 and $37.22 \mathrm{cmol} \mathrm{kg}^{-1}$; texture of soils samples were between clay (C) and sandy loam (SL).

Table 1: Some physical and chemical properties of the soil samples

\begin{tabular}{|c|c|c|c|c|c|c|}
\hline \multirow[t]{2}{*}{$\begin{array}{l}\text { Soil } \\
\text { no }\end{array}$} & \multirow[t]{2}{*}{$\begin{array}{c}\mathrm{pH} \\
(1: 2.5)\end{array}$} & \multirow[t]{2}{*}{$\mathrm{CaCO}_{3}, \%$} & \multirow{2}{*}{$\begin{array}{c}\text { CEC, } \\
\mathrm{cmol} \\
\mathrm{kg}^{-1}\end{array}$} & \multicolumn{3}{|c|}{$\begin{array}{l}\text { Particle size } \\
\text { distribution }\end{array}$} \\
\hline & & & & $\begin{array}{c}\text { Clay, } \\
\%\end{array}$ & $\begin{array}{l}\text { Silt, } \\
\%\end{array}$ & $\begin{array}{c}\text { Sand, } \\
\%\end{array}$ \\
\hline 1 & 7.01 & 1.20 & 22.65 & 32.9 & 26.8 & 40.3 \\
\hline 2 & 7.48 & 1.91 & 26.18 & 39.9 & 23.9 & 36.2 \\
\hline 3 & 7.30 & 0.30 & 16.44 & 11.6 & 18.8 & 69.6 \\
\hline 4 & 6.98 & 0.54 & 29.47 & 42.7 & 21.5 & 35.8 \\
\hline 5 & 7.30 & 3.47 & 26.55 & 43.4 & 17.5 & 39.1 \\
\hline 6 & 6.29 & 0.00 & 19.25 & 18.7 & 16.3 & 65.0 \\
\hline 7 & 7.50 & 4.02 & 24.43 & 27.6 & 31.1 & 41.3 \\
\hline 8 & 7.53 & 7.89 & 28.14 & 45.2 & 21.7 & 33.1 \\
\hline 9 & 7.66 & 8.55 & 26.32 & 30.6 & 22.0 & 47.4 \\
\hline 10 & 7.62 & 5.12 & 20.32 & 17.6 & 28.4 & 54.0 \\
\hline 11 & 7.67 & 15.10 & 28.25 & 27.2 & 16.2 & 46.6 \\
\hline 12 & 7.45 & 9.32 & 30.60 & 33.0 & 24.5 & 42.5 \\
\hline 13 & 7.30 & 0.90 & 28.73 & 20.7 & 24.3 & 55.1 \\
\hline 14 & 7.46 & 1.80 & 19.56 & 15.8 & 25.2 & 59.0 \\
\hline 15 & 7.32 & 0.38 & 37.22 & 48.0 & 11.9 & 40.1 \\
\hline 16 & 7.40 & 9.26 & 34.52 & 32.7 & 25.8 & 41.5 \\
\hline 17 & 7.34 & 1.22 & 30.46 & 23.2 & 29.3 & 47.5 \\
\hline 18 & 7.27 & 3.34 & 16.54 & 17.8 & 19.0 & 63.2 \\
\hline 19 & 7.64 & 4.20 & 22.06 & 23.4 & 23.9 & 52.7 \\
\hline 20 & 7.42 & 2.23 & 27.34 & 23.5 & 28.3 & 48.2 \\
\hline 21 & 7.52 & 7.85 & 34.15 & 56.8 & 18.9 & 24.3 \\
\hline 22 & 7.94 & 5.24 & 35.04 & 44.0 & 28.9 & 27.1 \\
\hline 23 & 7.83 & 12.36 & 29.50 & 40.1 & 26.9 & 33.0 \\
\hline 24 & 7.52 & 6.85 & 24.62 & 29.0 & 40.9 & 30.1 \\
\hline 25 & 7.47 & 3.21 & 20.48 & 22.4 & 30.2 & 47.4 \\
\hline
\end{tabular}

The available Fe contents of the soil samples were determined through eight different chemical extraction methods. These methods are $0.005 \mathrm{M}$ DTPA + 0.01M CaCl $2+0.1 \mathrm{M}$ TEA ([18]); $0.05 \mathrm{M}$ $\mathrm{HCl}+0.012 \mathrm{M} \mathrm{H}_{2} \mathrm{SO}_{4}$ ([35]); $1 \mathrm{M} \mathrm{NH}_{4} \mathrm{OAc}$ ([24]); $0.01 \mathrm{M}$ EDTA + $1 \mathrm{M} \mathrm{NH}_{4} \mathrm{OAc}([22]) ; 1 \mathrm{M} \mathrm{MgCl}{ }_{2}$ ([30]); $0.001 \mathrm{M}$ EDTA + $1 \mathrm{M}\left(\mathrm{NH}_{4}\right) \mathrm{CO}_{3}$ ([33]); $0.005 \mathrm{M} \mathrm{DTPA}+1 \mathrm{M} \mathrm{NH}_{4} \mathrm{HCO}_{3}$ ([29]) and $0.001 \mathrm{M}$ EDDHA ([13]). Some properties of these extraction methods are given in Table 2. 
Table 2: Chemical extraction methods were used for the determination of available Fe contents of the soil samples.

\begin{tabular}{|c|c|c|c|}
\hline Methods & $\begin{array}{c}\text { Soil - } \\
\text { solution } \\
\text { ratio }\end{array}$ & Shaking time & Reference \\
\hline $\begin{array}{c}0.005 \mathrm{M} \text { DTPA }+0.01 \mathrm{M} \mathrm{CaCl}_{2}+ \\
0.1 \mathrm{M} \text { TEA }\end{array}$ & $1: 2$ & 2 hours & Lindsay and Norvell (1978) \\
\hline $0.05 \mathrm{M} \mathrm{HCl}+0.012 \mathrm{M} \mathrm{H}_{2} \mathrm{SO}_{4}$ & $1: 4$ & 15 minutes & Wear and Evans (1968) \\
\hline $1 \mathrm{M} \mathrm{NH}_{4} \mathrm{OAc}(\mathrm{pH}: 4.8)$ & $1: 4$ & 30 minutes & Olson (1948) \\
\hline $0.01 \mathrm{M} \mathrm{EDTA}+1 \mathrm{M} \mathrm{NH}_{4} \mathrm{OAc}$ & $1: 10$ & 1 hour & Navrot and Ravikovitch(1968) \\
\hline $1 \mathrm{M} \mathrm{MgCl}_{2}$ & $1: 5$ & 45 minutes & Stewart and Berger (1965) \\
\hline $0.01 \mathrm{M}$ EDTA $+1 \mathrm{M}\left(\mathrm{NH}_{4}\right)_{2} \mathrm{CO}_{3}$ & $1: 2$ & 30 minutes & Trierweiler and Lindsay (1969) \\
\hline $0.005 \mathrm{M} \mathrm{DTPA}+1 \mathrm{M} \mathrm{NH}_{4} \mathrm{HCO}_{3}$ & $1: 2$ & 15 minutes & Soltanpour (1991) \\
\hline $0.001 \mathrm{M}$ EDDHA & $1: 2$ & 10 minutes & Johnson and Young (1973) \\
\hline
\end{tabular}

A greenhouse experiment was designed in a randomised complete block replicated three times. Air dried $2.5 \mathrm{~kg}$ soil was filled into plastic pots. Barley (Hordeum vulgare L.) was used as a test plant because it is sensitive to Fe deficiency ([21]). Each pot was fertilized with $140 \mathrm{mg} \mathrm{kg}^{-1} \mathrm{~N}\left(\mathrm{NH}_{4} \mathrm{NO}_{3}\right)$ and $80 \mathrm{mg} \mathrm{kg}{ }^{-1} \mathrm{P}_{2} \mathrm{O}_{5}\left(\mathrm{KH}_{2} \mathrm{PO}_{4}\right)$, according to average application rates of $\mathrm{N}$ and $\mathrm{P}_{2} \mathrm{O}_{5}$ to barley in this region. Four different rates of $\mathrm{Fe}\left(\mathrm{Fe}_{0}: 0 ; \mathrm{Fe}_{1}: 10\right.$; $\mathrm{Fe}_{2}: 20$; and $\mathrm{Fe}_{3}: 30 \mathrm{mg} \mathrm{kg}^{-1}$ ) were applied to soils as Fe-EDDHA compound. Fifteen plants were left in each pot after the germination. The water content of the pots was adjusted to $70 \%$ of field capacity during the experiment period. Barley shoots were harvested after 60 days. Harvested shoots were washed once in tap water and twice in distilled water and dried at $65{ }^{0} \mathrm{C}$. Dry matter yields were determined.

Dried and ground plant materials were digested using $\mathrm{HNO}_{3}+\mathrm{HClO}_{4}$ ([14]). The $\mathrm{Fe}$ concentrations of plants were determined with AA-660 Shimadzu Atomic Absorption Spectrophotometer (AAS) ([15]). Dry matter yield, Fe concentration, Fe uptake and the relative values of these biological indices were used as biological method. Relative biological indices were calculated as $\mathrm{Fe}_{0} / \mathrm{Fe}_{\text {maximum biological indice }} \mathrm{X} 100$.

Correlation coefficients ( $r$ ) were measured between available Fe content of the soils according to eight different methods and biological indices (dry matter yield, $\mathrm{Fe}$ concentration, $\mathrm{Fe}$ uptake, relative dry matter yield, relative $\mathrm{Fe}$ concentration and relative $\mathrm{Fe}$ uptake) of barley plants. Significance of the correlation coefficients (r) was checked at the 1 and $5 \%$ levels ([37]).

The extraction method which displayed the highest correlation coefficient (r) with the biological indices was recommended for the determination of available
Fe content of the soils of Edirne Province.This approach for selecting extracting methods has been used before in the determination of suitable methods for many plant nutrients ([1], [2], [3],[4], [8], [25], [36]).

\section{RESULTS AND DISCUSSION}

\section{Effect of Increasing Fe Application Rates on Barley Yields, Fe Concentration and Fe Uptake}

Dry matter yield of the barley plants was affected by the Fe application. While the highest dry matter yield on 18 soils was obtained from the $\mathrm{Fe}_{2}\left(20 \mathrm{mgkg}^{-1}\right)$, the highest dry matter yield on 7 soils was obtained with $\mathrm{Fe}_{3}$ (30 mg kg-1) (table 3)

In general, the 18 soils, which gave the highest dry matter, yield at $\mathrm{Fe}_{2}\left(20 \mathrm{mg} \mathrm{kg}^{-1}\right)$, were those with the highest levels of available $\mathrm{Fe}$ (Table 4). In these soils, $\mathrm{Fe}_{3}$ appears to have caused possible toxic effects.

The Fe concentration and Fe uptake of the plants increased with increasing Fe application (Table 3). $\mathrm{Fe}$ concentration of plants determined varied between 83 and $161 \mathrm{mg} \mathrm{kg}^{-1}$, all of these values except for one i.e. $161 \mathrm{mg} \mathrm{kg}^{-1}$, for barley and were sufficient ([26]).

In general dry matter yield using $\mathrm{Fe}_{2}$ concentration of the barley plants was determined to be higher for the soils $1,2,8,9,11,12,13,14,15,16,17,18,20,21$, 22, 23, 24 and 25 (Table 3). The reason of this result maybe the higher available Fe content in this soils.

The effect of Fe application on the biological indices of the barley plants was determined to be significant at $1 \%$ level and the results obtained are in agreement with earlier reports ([3], [5], [7]). 
Table 3: The effect of Fe application on biological indices of barley

\begin{tabular}{|c|c|c|c|c|c|c|c|c|c|c|c|c|}
\hline \multirow{2}{*}{$\begin{array}{c}\text { Soil } \\
\text { no }\end{array}$} & \multicolumn{4}{|c|}{ Dry matter yield, $\mathrm{g}_{\text {pot }}{ }^{-1}$} & \multicolumn{4}{|c|}{ Fe concentration of plant, mg. $\mathrm{kg}^{-1}$} & \multicolumn{4}{|c|}{ Uptake of Fe by shoots, $\mu$ g.pot ${ }^{-1}$} \\
\hline & $\mathrm{Fe}_{0}$ & $\mathrm{Fe}_{1}$ & $\mathrm{Fe}_{2}$ & $\mathrm{Fe}_{3}$ & $\mathrm{Fe}_{0}$ & $\mathrm{Fe}_{1}$ & $\mathrm{Fe}_{2}$ & $\mathrm{Fe}_{3}$ & $\mathrm{Fe}_{0}$ & $\mathrm{Fe}_{1}$ & $\mathrm{Fe}_{2}$ & $\mathrm{Fe}_{3}$ \\
\hline 1 & $2.41 \mathrm{a}$ & $2.57 \mathrm{~b}$ & $2.72 \mathrm{c}$ & $2.61 \mathrm{~b}$ & $94 \mathrm{a}$ & $101 \mathrm{~b}$ & $113 \mathrm{c}$ & $119 \mathrm{~d}$ & $227 \mathrm{a}$ & $260 \mathrm{~b}$ & $307 \mathrm{c}$ & $311 \mathrm{c}$ \\
\hline 2 & $2.24 \mathrm{a}$ & $2.34 \mathrm{~b}$ & $2.48 \mathrm{c}$ & $2.37 \mathrm{c}$ & $83 \mathrm{a}$ & $94 \mathrm{~b}$ & $98 \mathrm{~b}$ & $110 \mathrm{c}$ & $186 \mathrm{a}$ & $220 \mathrm{~b}$ & $243 \mathrm{c}$ & $261 \mathrm{c}$ \\
\hline 3 & $1.91 \mathrm{a}$ & $2.02 \mathrm{~b}$ & $2.19 \mathrm{c}$ & $2.12 \mathrm{c}$ & $97 \mathrm{a}$ & $102 \mathrm{~b}$ & $110 \mathrm{c}$ & $118 \mathrm{~d}$ & $185 \mathrm{a}$ & $206 \mathrm{a}$ & $241 \mathrm{~b}$ & $250 \mathrm{~b}$ \\
\hline 4 & $3.55 \mathrm{a}$ & $3.67 \mathrm{~b}$ & $3.80 \mathrm{bc}$ & $3.71 \mathrm{~b}$ & $104 \mathrm{a}$ & $110 \mathrm{~b}$ & $121 \mathrm{c}$ & $127 \mathrm{~d}$ & $369 \mathrm{a}$ & $404 \mathrm{~b}$ & $460 \mathrm{c}$ & $471 \mathrm{c}$ \\
\hline 5 & $3.40 \mathrm{a}$ & $3.62 b c$ & $3.70 \mathrm{c}$ & $3.58 \mathrm{~b}$ & $108 \mathrm{a}$ & $113 \mathrm{~b}$ & $118 \mathrm{c}$ & $122 \mathrm{c}$ & $367 \mathrm{a}$ & $409 \mathrm{~b}$ & $437 \mathrm{c}$ & $437 \mathrm{c}$ \\
\hline 6 & $1.98 \mathrm{a}$ & $2.25 \mathrm{~b}$ & $2.47 \mathrm{c}$ & $2.40 \mathrm{c}$ & $98 \mathrm{a}$ & $107 \mathrm{~b}$ & $119 \mathrm{c}$ & $123 \mathrm{c}$ & $194 \mathrm{a}$ & $241 \mathrm{~b}$ & $294 \mathrm{c}$ & $295 \mathrm{c}$ \\
\hline 7 & $2.59 \mathrm{a}$ & $2.71 b$ & $2.83 \mathrm{c}$ & $2.75 b c$ & $116 \mathrm{a}$ & $121 \mathrm{~b}$ & $125 \mathrm{~b}$ & $134 \mathrm{c}$ & $300 \mathrm{a}$ & $328 \mathrm{~b}$ & $354 \mathrm{c}$ & $369 \mathrm{c}$ \\
\hline 8 & $2.80 \mathrm{a}$ & $3.07 \mathrm{~b}$ & $3.26 \mathrm{c}$ & $3.15 b$ & $103 \mathrm{a}$ & $133 \mathrm{~b}$ & $139 \mathrm{c}$ & $147 \mathrm{~d}$ & $288 \mathrm{a}$ & $408 \mathrm{~b}$ & $453 \mathrm{c}$ & $439 c$ \\
\hline 9 & $2.38 \mathrm{a}$ & $2.58 \mathrm{~b}$ & $2.72 \mathrm{c}$ & $2.60 \mathrm{~b}$ & $95 \mathrm{a}$ & $104 \mathrm{~b}$ & $119 \mathrm{c}$ & $130 \mathrm{~d}$ & $226 \mathrm{a}$ & $268 \mathrm{~b}$ & $324 \mathrm{c}$ & $338 \mathrm{c}$ \\
\hline 10 & $1.73 \mathrm{a}$ & $1.95 \mathrm{~b}$ & $2.19 \mathrm{c}$ & $2.10 \mathrm{c}$ & $97 \mathrm{a}$ & $118 \mathrm{~b}$ & $130 \mathrm{c}$ & $135 \mathrm{~d}$ & $168 \mathrm{a}$ & $230 \mathrm{~b}$ & $285 \mathrm{c}$ & $284 \mathrm{c}$ \\
\hline 11 & $1.78 \mathrm{a}$ & $1.97 \mathrm{~b}$ & $2.28 \mathrm{c}$ & $2.14 b$ & $94 \mathrm{a}$ & $117 \mathrm{~b}$ & $129 \mathrm{c}$ & $134 \mathrm{~d}$ & $167 \mathrm{a}$ & $230 \mathrm{~b}$ & $294 \mathrm{c}$ & $289 \mathrm{c}$ \\
\hline 12 & $2.56 \mathrm{a}$ & $2.69 \mathrm{~b}$ & $2.87 \mathrm{~d}$ & $2.72 \mathrm{c}$ & $98 \mathrm{a}$ & $116 \mathrm{~b}$ & $125 \mathrm{c}$ & $131 \mathrm{~d}$ & $251 \mathrm{a}$ & $312 \mathrm{~b}$ & $359 \mathrm{c}$ & $356 \mathrm{c}$ \\
\hline 13 & $1.82 \mathrm{a}$ & $1.95 \mathrm{~b}$ & $2.19 \mathrm{~d}$ & $2.07 \mathrm{c}$ & $88 \mathrm{a}$ & $107 \mathrm{~b}$ & $114 \mathrm{c}$ & $120 \mathrm{~d}$ & $160 \mathrm{a}$ & $209 \mathrm{~b}$ & $250 \mathrm{c}$ & $248 \mathrm{c}$ \\
\hline 14 & $1.69 \mathrm{a}$ & $1.75 \mathrm{ab}$ & $1.94 \mathrm{c}$ & $1.80 \mathrm{~b}$ & $97 \mathrm{a}$ & $113 \mathrm{~b}$ & $127 \mathrm{c}$ & $138 \mathrm{~d}$ & $164 \mathrm{a}$ & $198 \mathrm{~b}$ & $246 \mathrm{c}$ & $248 \mathrm{c}$ \\
\hline 15 & $2.87 \mathrm{a}$ & $3.02 b$ & $3.27 \mathrm{~d}$ & $3.14 \mathrm{c}$ & $101 \mathrm{a}$ & $117 \mathrm{~b}$ & $129 \mathrm{c}$ & $140 \mathrm{~d}$ & $290 \mathrm{a}$ & $353 \mathrm{~b}$ & $422 \mathrm{c}$ & $440 \mathrm{c}$ \\
\hline 16 & $2.65 \mathrm{a}$ & $2.84 b$ & $3.18 \mathrm{~d}$ & $3.04 \mathrm{c}$ & $92 \mathrm{a}$ & $110 \mathrm{~b}$ & $127 \mathrm{c}$ & $139 \mathrm{~d}$ & $244 \mathrm{a}$ & $312 \mathrm{~b}$ & $404 \mathrm{c}$ & $423 \mathrm{c}$ \\
\hline 17 & $2.48 \mathrm{a}$ & $2.72 b$ & $2.94 \mathrm{c}$ & $2.80 \mathrm{~b}$ & $105 \mathrm{a}$ & $117 \mathrm{~b}$ & $130 \mathrm{c}$ & $141 \mathrm{~d}$ & $260 \mathrm{a}$ & $318 \mathrm{~b}$ & $382 \mathrm{c}$ & $395 \mathrm{c}$ \\
\hline 18 & $1.76 \mathrm{a}$ & $1.89 \mathrm{~b}$ & $2.04 \mathrm{c}$ & $1.92 \mathrm{~b}$ & $93 \mathrm{a}$ & $110 \mathrm{~b}$ & $129 \mathrm{c}$ & $134 \mathrm{~d}$ & $164 \mathrm{a}$ & $208 \mathrm{~b}$ & $263 \mathrm{c}$ & $257 \mathrm{c}$ \\
\hline 19 & $1.94 \mathrm{a}$ & $2.17 \mathrm{~b}$ & $2.30 \mathrm{c}$ & $2.21 b c$ & $99 \mathrm{a}$ & $114 \mathrm{~b}$ & $130 \mathrm{c}$ & $140 \mathrm{~d}$ & $192 \mathrm{a}$ & $247 \mathrm{~b}$ & $299 \mathrm{c}$ & $309 \mathrm{c}$ \\
\hline 20 & $1.72 \mathrm{a}$ & $1.92 \mathrm{~b}$ & $2.27 \mathrm{~d}$ & $2.14 \mathrm{c}$ & $101 \mathrm{a}$ & $120 \mathrm{~b}$ & $134 \mathrm{c}$ & $141 \mathrm{~d}$ & $174 \mathrm{a}$ & $230 \mathrm{~b}$ & $304 \mathrm{c}$ & $302 c$ \\
\hline 21 & $2.86 a$ & $3.12 b$ & $3.29 \mathrm{c}$ & $3.17 \mathrm{~b}$ & $105 \mathrm{a}$ & $120 \mathrm{~b}$ & $139 \mathrm{c}$ & $147 \mathrm{~d}$ & $300 \mathrm{a}$ & $374 b$ & $457 \mathrm{c}$ & $466 c$ \\
\hline 22 & $3.26 \mathrm{a}$ & $3.42 \mathrm{~b}$ & $3.64 c$ & $3.51 \mathrm{~b}$ & $103 \mathrm{a}$ & $117 \mathrm{~b}$ & $132 \mathrm{c}$ & $145 \mathrm{~d}$ & $336 \mathrm{a}$ & $400 \mathrm{~b}$ & $480 \mathrm{c}$ & $509 \mathrm{~d}$ \\
\hline 23 & $3.40 \mathrm{a}$ & $3.60 \mathrm{~b}$ & $3.81 \mathrm{~d}$ & $3.70 \mathrm{c}$ & $105 \mathrm{a}$ & $119 \mathrm{~b}$ & $142 \mathrm{c}$ & $161 \mathrm{~d}$ & $357 \mathrm{a}$ & $428 \mathrm{~b}$ & $541 \mathrm{c}$ & $596 \mathrm{~d}$ \\
\hline 24 & $2.47 \mathrm{a}$ & $2.71 \mathrm{~b}$ & $2.90 \mathrm{c}$ & $2.79 b$ & $116 \mathrm{a}$ & $127 \mathrm{~b}$ & $139 \mathrm{c}$ & $150 \mathrm{~d}$ & $287 \mathrm{a}$ & $344 \mathrm{~b}$ & $403 \mathrm{c}$ & $419 \mathrm{c}$ \\
\hline 25 & $2.56 \mathrm{a}$ & $2.71 b$ & $2.89 \mathrm{c}$ & $2.76 \mathrm{~b}$ & $105 \mathrm{a}$ & $116 \mathrm{~b}$ & $129 \mathrm{c}$ & $142 \mathrm{~d}$ & $269 \mathrm{a}$ & $350 \mathrm{~b}$ & $373 \mathrm{c}$ & $392 c$ \\
\hline $\begin{array}{c}\text { LSD } \\
\% 1\end{array}$ & \multicolumn{4}{|c|}{0.10} & \multicolumn{4}{|c|}{4.50} & \multicolumn{4}{|c|}{21} \\
\hline
\end{tabular}

*: Significant differences between biological indices at $\mathrm{p}<1 \%$ level indicated by different letters.

\section{The Fe Contents of Soils According to Different Extraction Methods}

Eight extraction methods were used for the determination of available $\mathrm{Fe}$ content of the soil samples. (Table 4). Available Fe varied widely depending on the extraction method used, reasons for which could be pointed out as the type, concentration, $\mathrm{pH}$, shaking time, soil solution ratio of the extraction solution and variability observed in the physical and chemical properties of the soils used.

Some physical and chemical properties of soils affected the availability of $\mathrm{Fe}$ to plants. The causes of low $\mathrm{Fe}$ availability are coarse texture, high $\mathrm{pH}$ and lime, low CEC and organic matter content in soils ([7], [19]).

Table 4 shows that available Fe contents of the soils $8,9,11,12,21$ and 23 determined by various methods were lower than in the rest of the soils, which may have been induced by the $\mathrm{pH}$ values and lime contents of the soils (Table 1). On the other hand available Fe contents of the soils 4, 6, 15 and 17 with low lime and $\mathrm{pH}$ levels were higher. Similarly lower available Fe content was determined in the soils 3,10,14 and 18 of lower clay content and CEC than the soils 4, 5, 15, 17 and 22 of high clay and CEC values, which demonstrates that available Fe content is influenced by physical and chemical properties of soils ([6], [20]).

As shown in Table 4, higher available Fe content of soil samples was determined with the $0.005 \mathrm{M}$ DTPA $+0.01 \mathrm{M} \mathrm{CaCl}_{2}+0.1 \mathrm{M}$ TEA; $0.005 \mathrm{M} \mathrm{DTPA}+1$ $\mathrm{M} \mathrm{NH} \mathrm{NHCO}_{3}$ and $0.001 \mathrm{M}$ EDDHA methods in comparison to other extraction methods. On the other hand, the lowest available Fe content of soil samples was determined with the $1 \mathrm{M} \mathrm{NH}_{4} \mathrm{OAc}$ and the $1 \mathrm{M}$ $\mathrm{MgCl}_{2}$ methods. 
Table 4: Fe content in soils obtained by chemical extraction methods

\begin{tabular}{|c|c|c|c|c|c|c|c|c|}
\hline \multirow[t]{2}{*}{ Soil no } & \multicolumn{8}{|c|}{ Fe content in soils, $\mathrm{mg} \mathrm{kg}^{-1}$} \\
\hline & $\begin{array}{c}\text { DTPA }+\mathrm{CaCl}_{2} \\
+ \text { TEA }\end{array}$ & $\begin{array}{l}\mathrm{HCl}+ \\
\mathrm{H}_{2} \mathrm{SO}_{4}\end{array}$ & $\mathrm{NH}_{4} \mathrm{OAc}$ & $\begin{array}{c}\text { EDTA } \\
+\mathrm{NH}_{4} \mathrm{OAc}\end{array}$ & $\mathrm{MgCl}_{2}$ & $\begin{array}{c}\mathrm{EDTA}+(\mathrm{NH} \\
\left.{ }_{4}\right)_{2} \mathrm{CO}_{3}\end{array}$ & $\begin{array}{c}\text { DTPA } \\
+\mathrm{NH}_{4} \mathrm{HCO}_{3}\end{array}$ & EDDHA \\
\hline 1 & 3.6 & 0.8 & 0.8 & 3.4 & 0.8 & 0.6 & 3.4 & 2.2 \\
\hline 2 & 2.4 & 2.2 & 0.8 & 3.8 & 2.0 & 0.8 & 2.2 & 2.0 \\
\hline 3 & 2.2 & 0.6 & 1.8 & 3.1 & 0.8 & 0.4 & 4.1 & 3.4 \\
\hline 4 & 5.6 & 3.6 & 2.4 & 5.6 & 3.4 & 3.8 & 5.8 & 4.8 \\
\hline 5 & 5.0 & 3.2 & 2.0 & 4.2 & 3.0 & 3.0 & 4.0 & 4.3 \\
\hline 6 & 4.5 & 2.6 & 1.0 & 4.0 & 1.9 & 2.8 & 1.8 & 5.2 \\
\hline 7 & 4.2 & 3.5 & 1.2 & 4.2 & 2.4 & 2.5 & 4.2 & 3.8 \\
\hline 8 & 2.6 & 2.6 & 1.0 & 4.0 & 2.0 & 0.4 & 4.7 & 2.4 \\
\hline 9 & 3.2 & 1.0 & 0.9 & 2.4 & 1.6 & 0.8 & 3.8 & 4.0 \\
\hline 10 & 2.4 & 1.8 & 1.4 & 1.8 & 1.4 & 2.2 & 2.2 & 2.8 \\
\hline 11 & 2.8 & 1.0 & 0.2 & 2.1 & 0.2 & 0.6 & 1.4 & 1.8 \\
\hline 12 & 3.5 & 1.2 & 0.6 & 3.8 & 0.7 & 3.8 & 4.1 & 2.3 \\
\hline 13 & 3.0 & 1.9 & 1.8 & 3.4 & 2.0 & 1.0 & 3.4 & 1.8 \\
\hline 14 & 3.0 & 1.4 & 2.6 & 3.8 & 1.0 & 1.2 & 2.4 & 2.2 \\
\hline 15 & 5.8 & 2.6 & 1.6 & 5.4 & 2.2 & 3.8 & 4.8 & 3.6 \\
\hline 16 & 4.2 & 1.4 & 1.3 & 4.8 & 0.2 & 3.9 & 4.6 & 4.1 \\
\hline 17 & 5.6 & 3.4 & 1.2 & 4.8 & 3.4 & 4.0 & 4.2 & 3.8 \\
\hline 18 & 4.1 & 3.6 & 0.4 & 3.4 & 2.4 & 2.6 & 3.4 & 2.8 \\
\hline 19 & 2.2 & 0.6 & 0.6 & 3.8 & 0.8 & 0.4 & 3.6 & 1.4 \\
\hline 20 & 3.4 & 3.1 & 0.6 & 1.8 & 1.6 & 3.2 & 3.3 & 2.2 \\
\hline 21 & 4.2 & 2.2 & 1.4 & 1.6 & 1.0 & 0.5 & 4.6 & 4.2 \\
\hline 22 & 4.8 & 2.4 & 1.0 & 4.1 & 1.0 & 3.6 & 3.0 & 3.7 \\
\hline 23 & 3.8 & 2.4 & 0.6 & 4.0 & 1.3 & 4.0 & 3.8 & 3.0 \\
\hline 24 & 4.2 & 0.8 & 1.7 & 3.6 & 1.6 & 2.4 & 3.6 & 3.2 \\
\hline 25 & 4.0 & 2.4 & 1.2 & 4.0 & 2.0 & 3.4 & 3.2 & 3.4 \\
\hline Mean & 3.77 & 2.09 & 1.19 & 3.62 & 1.67 & 2.21 & 3.58 & 3.14 \\
\hline
\end{tabular}

These results also show that higher available Fe was determined using methods with chelate + salt $(0.005$ $\mathrm{M}$ DTPA + $0.01 \mathrm{M} \mathrm{CaCl}_{2}+0.1 \mathrm{M}$ TEA; $0.005 \mathrm{M}$ $\mathrm{DTPA}+1 \mathrm{M} \mathrm{NH} \mathrm{HCO}_{3} ; 0.01 \mathrm{M}$ EDTA $+1 \mathrm{M}$ $\mathrm{NH}_{4} \mathrm{OAc}$ and $0.01 \mathrm{M}$ EDTA $+1 \mathrm{M}\left(\mathrm{NH}_{4}\right)_{2} \mathrm{CO}_{3}$ methods) and chelate alone (0.001 $\mathrm{M}$ EDDHA) in comparison to the methods using salt $\left(1 \mathrm{M} \mathrm{NH}_{4} \mathrm{OAc}\right.$ and $1 \mathrm{M} \mathrm{MgCl}_{2}$ methods) and acid $(0.05 \mathrm{M} \mathrm{HCl}+$ $0.012 \mathrm{M} \mathrm{H}_{2} \mathrm{SO}_{4}$ method). Mean available Fe content of the soils was determined to be $3.77 ; 2.09 ; 1.19$; $3.62 ; 1.67 ; 2.21 ; 3.58$ and $3.14 \mathrm{mg} \mathrm{kg}^{-1}$, using the methods $0.005 \mathrm{M}$ DTPA + $0.01 \mathrm{M} \mathrm{CaCl}_{2}+0.1 \mathrm{M}$ TEA; $0.05 \mathrm{M} \mathrm{HCl}+0.012 \mathrm{M} \mathrm{H}_{2} \mathrm{SO}_{4} ; 1 \mathrm{M} \mathrm{NH}_{4} \mathrm{OAc}$; $0.01 \mathrm{M}$ EDTA + $1 \mathrm{M} \mathrm{NH}_{4} \mathrm{OAc} ; 1 \mathrm{M} \mathrm{MgCl}_{2} ; 0.01 \mathrm{M}$ EDTA $+1 \mathrm{M}\left(\mathrm{NH}_{4}\right)_{2} \mathrm{CO}_{3} ; 0.005 \mathrm{M} \mathrm{DTPA}+1 \mathrm{M}$ $\mathrm{NH}_{4} \mathrm{HCO}_{3}$ and $0.001 \mathrm{M}$ EDDHA, respectively. The acid and salt methods of $\mathrm{HCl}+\mathrm{H}_{2} \mathrm{SO}_{4}, \mathrm{MgCl}_{2}$ and $\mathrm{NH}_{4} \mathrm{OAc}$, which gave lowest available $\mathrm{Fe}$, are not recommended for the determination of $\mathrm{Fe}$ content in neutral and alkaline soils. The use of chelate and chelate + salt methods are suggested in these type of soils ([15]).

\section{The Relationships Between Chemical Extraction Methods and Biological Indices}

The correlation coefficients (r) determined between chemical extraction methods and biological indices are given in Table 5. Significant correlation coefficients were observed between all chemical extraction methods, except $1 \mathrm{M} \mathrm{NH}_{4} \mathrm{OAc}$ method and the biological indices (dry matter yield, Fe concentration, $\mathrm{Fe}$ uptake, relative dry matter yield, relative Fe concentration, and relative Fe uptake) at 1 $\%$ level (Table 5). According to Table 5, the highest correlation coefficients ( $\mathrm{r}$ ) were determined between $0.005 \mathrm{M} \mathrm{DTPA}+0.01 \mathrm{M} \mathrm{CaCl}_{2}+0.1 \mathrm{M}$ TEA and $0.005 \mathrm{M}$ DTPA $+1 \mathrm{M} \mathrm{NH} \mathrm{NCO}_{3}$ methods and biological indices. These correlation coefficients (r) determined were $0.621^{* *} ; 0.823^{* *} ; 0.810^{* *}$; $0.433^{* *} ; 0.558^{* *}$ and $0.640^{* *}$ for $0.005 \mathrm{M} \mathrm{DTPA}+$ $0.01 \mathrm{M} \mathrm{CaCl}_{2}+0.1$ TEA method and $0.618^{* *}$; $0.520^{* *} ; 0.679^{* *} ; 0.521^{* *} ; 0.492^{* *}$ and $0.641^{* *}$ for

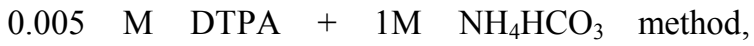
respectively. The results obtained from the $0.001 \mathrm{M}$ 
EDDHA method followed the above methods regarding the correlation coefficients (r).

According to the results the order of significance for the extraction methods are as follows: $0.005 \mathrm{M}$ $\mathrm{DTPA}+0.01 \mathrm{M} \mathrm{CaCl}_{2}+0.1 \mathrm{M} \mathrm{TEA}>0.005 \mathrm{M}$
DTPA $+1 \mathrm{M} \mathrm{NH}_{4} \mathrm{HCO}_{3}>0.001 \mathrm{M}$ EDDHA $>0.01$ $\mathrm{M}$ EDTA $+1 \mathrm{M} \mathrm{NH}_{4} \mathrm{OAc}>0.01 \mathrm{M}$ EDTA $+1 \mathrm{M}$ $\left(\mathrm{NH}_{4}\right)_{2} \mathrm{CO}_{3}>0.05 \mathrm{M} \mathrm{HCl}+0.012 \mathrm{M} \mathrm{H}_{2} \mathrm{SO}_{4}>1 \mathrm{M}$ $\mathrm{MgCl}_{2}>1 \mathrm{M} \mathrm{NH}_{4} \mathrm{OAc}$.

Table5: The correlation coefficients (r) for the relationship between chemical extraction methods and biological indices

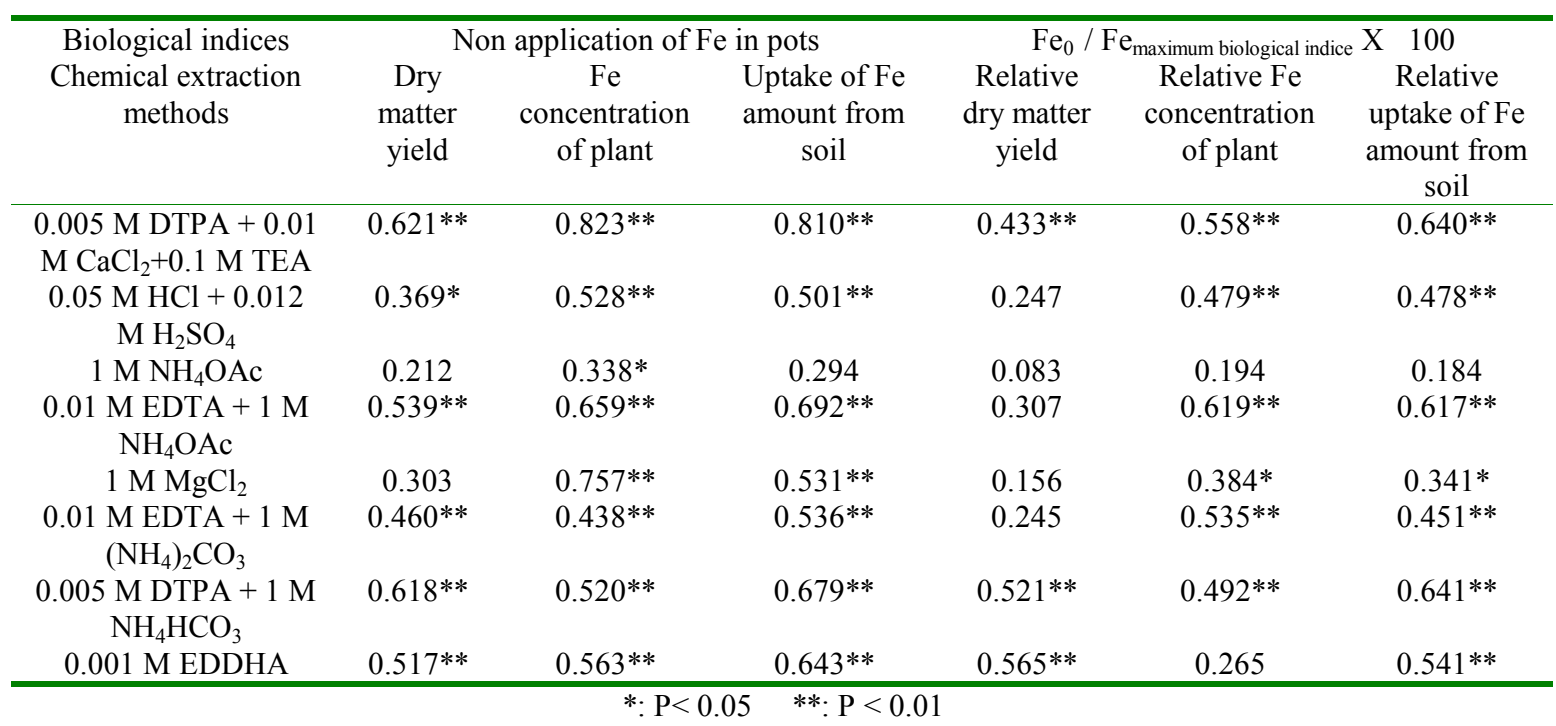

\section{CONCLUSION}

The available $\mathrm{Fe}$ content of the soil samples were determined to be either insufficient or moderately sufficient according to different extraction methods. Supports earlier researchs in this region ([9], [27]).

Chemical properties of the soils studied show that they are neutral to slightly alkaline and contained medium level of lime (Table 1). Use of acid ( $\mathrm{HCl}+$ $\left.\mathrm{H}_{2} \mathrm{SO}_{4}\right)$ and salt $\left(\mathrm{NH}_{4} \mathrm{OAc}, \mathrm{MgCl}_{2}\right)$ extraction methods are inadequate in the determination of available $\mathrm{Fe}$ content and chelate (EDDHA) and chelate + salt mix (DTPA $+\mathrm{NH}_{4} \mathrm{HCO}_{3}$; DTPA + $\mathrm{CaCl}_{2}+$ TEA; EDTA $+\mathrm{NH}_{4} \mathrm{OAc}$ and EDTA + $\left(\mathrm{NH}_{4}\right)_{2} \mathrm{CO}_{3}$ methods) were determined to be more suitable in the determination of available Fe content for such soils ([15]), supporting which in the present work, highest correlation coefficients (r) were obtained from the chelate and chelate + salt mix methods (Table 5). As a results, when considered the chemical properties of the soils studied chelate and chelate + salt mix methods can be used with satisfaction in the determination of available $\mathrm{Fe}$ contents of the Edirne region soils.
The $0.005 \mathrm{M}$ DTPA $+0.01 \mathrm{M} \mathrm{CaCl}_{2}+0.1 \mathrm{M}$ TEA; $0.005 \mathrm{M} \mathrm{DTPA}+1 \mathrm{M} \mathrm{NH}_{4} \mathrm{HCO}_{3}$ and $0.001 \mathrm{M}$ EDDHA methods, among the others, can be used confidently to determine the available Fe content of the soils of Edirne region because the highest correlation coefficients $(\mathrm{r})$ were determined when these methods were used (Table 5). These methods were also suggested for various regional soils ([3], [7], [11]). The 0.005 M DTPA + 0.01 $\mathrm{M} \mathrm{CaCl}_{2}+0.1$ $\mathrm{M}$ TEA method can be used in the determination of the available $\mathrm{Fe}$ content in this region and zinc $(\mathrm{Zn})$, copper $(\mathrm{Cu})$ and manganese $(\mathrm{Mn})$ contents can be determined in addition and this characteristic of this method therefore is to be taken into consideration when selecting a method.

Consequently all of the following methods i.e. 0.005 $\mathrm{M} \mathrm{DTPA}+0.01 \mathrm{M} \mathrm{CaCl}_{2}+0.1 \mathrm{M} \mathrm{TEA} ; 0.005 \mathrm{M}$ DTPA $+1 \mathrm{M} \mathrm{NH}_{4} \mathrm{HCO}_{3}$ and $0.001 \mathrm{M}$ EDDHA can be recommended in the determination of available $\mathrm{Fe}$ content of Edirne region soils because of the highest correlation coefficients ( $r$ ) determined. On the other hand, these methods are suitable to certain physical and chemical properties of the soils in this region. 


\section{REFERENCES}

[1] Akman, I. and Yýldýz, N. 1999. Evaluation of potassium status of Daphan Plain soils and suitability of different chemical methods used to determine plant available soil potassium of this soils. Journal of Faculty of Agriculture, Atatürk University, 30 (1): 15-24, (in Turkish).

[2] Arriechi, E. and Ramrirez, R. 1997. Soil test for available zinc in acid soils of Venezuela. Commun. Soil Sci. Plant Anal. 28 (17-18): 1471-1480.

[3] Aydemir, O. 1981. Comparison of various chemical extraction methods in predicting plant available soil iron. Turkish Journal of Doða, 5: 213-220, (in Turkish).

[4] Aydemir, O. and Köleli, N. 1996. Comparison of chemical extraction methods for plant available soil zinc in Harran Plain Soils. Turkish Journal of Agriculture and Forestry, 20 (2): 9198, (in Turkish).

[5] $\mathrm{Ba}^{\circ}$ ar, H. and Özgümü ${ }^{\circ}$ A. 1999. Effects of various iron fertilizers and rates on some micro nutrients contents of peach trees. Turkish Journal of Agriculture and Forestry, 23 (3): 273-281, (in Turkish).

[6] Bloom, P. R. and Inskeep, W. P. 1988. Factors affecting bicarbonate chemistry and iron chlorosis in soils. J. Plant Nutr. 9: 215-228.

[7] Elinç, F. 1997. Plant available $\mathrm{Zn}, \mathrm{Fe}, \mathrm{Mn}, \mathrm{Cu}$ and $\mathrm{B}$ status of Vertisol and Non-Calcareous Soils in Meriç Basin. Proceedings of Thrace I. Soil and Fertilizer Symposium, 20-22 October, Tekirdag, pp.119-126, (in Turkish).

[8] Elkarim, A. K. H. A. and Usta, S. 2001. Evaluation of some chemical extraction methods used as indices of soil nitrogen availability in Polatlý State farm Soils in Ankara Province. Turkish Journal of Agriculture and Forestry, 25(5): 337-345.

[9] Eyüpoglu, F.; Kurucu, N. and Talaz, S. 1998. Plant available trace element $(\mathrm{Fe}, \mathrm{Cu}, \mathrm{Zn}, \mathrm{Mn})$ status of Turkish soils. Soil and Fertilizer Res. Inst. Publ. p.72, (in Turkish).

[10] Gee, G. W. and Bauder, J., W. 1986. Particle size analysis. In Klute, A. (ed.), Methods of soil analysis, Part 1, Physical and mineralogical methods, Agronomy Monograph no. 9, (2nd edition), p: 383-411.
[11] Haddad, K. S. and Evans, J. C. 1993. Assesment of chemical methods for extracting zinc, manganese, copper and iron from New South Wales Soils. Comm. in Soil Sci. and Plant Anal. 24: 1- 2, 29-44.

[12] Hatipoglu, F. 1981. The available Fe status of apple grown in Central South Anatolia Soils and evaluation of chemical extraction methods used to determine plant available Fe contents in these soils. Ankara University, Agricultural Faculty Publ. No: 787, p.67, (in Turkish).

[13] Johnson, G. V: and Young, R. A. 1973. Evaluation of EDDHA as an extraction and analytical reagent for assesing the iron status of soils. Soil Sci. 115: 11-17.

[14] Kacar, B., 1972. Chemical analyses of plant and soil, II. Plant Analyses, Ankara University, Agricultural Faculty Publ. No: 453, p.646, (in Turkish).

[15] Kacar, B., 1995. Chemical analyses of plant and soil, III. Soil Analyses, Ankara University, Agricultural Faculty Res. and Develop.Publ. No: 3, p.706, (in Turkish).

[16] Loeppert, R. H. and Iskeep, W. P. 1996. Iron p. 639- 664. In D. L. Sparks et al. (ed.) Methods of Soil Analysis, Part 3, Chemical Methods, ,Book series No 5 SSSA and ASA, Madison.

[17] Loeppert, R. H. and Suarez, D. L., 1996. Carbonate and gypsium. p: 437-474. In D: L. Sparks et al. (ed.). Methods of soil analysis, Part 3, Chemical methods, SSSA Book series no: 5, SSSA and ASA, Madison.

[18] Lindsay, W. L. and Norvell, W. A. 1978. Development of a DTPA soil test for zinc, iron, manganese and copper. Soil Sci. Amer. J. 42 : 421- 428 .

[19] Lindsay, W. L. and Schwab, A. P. 1982. The chemistry of iron in soils and its availability to plants. J. Plant Nutr. 5: $821-840$.

[20] Marschner, H. 1995. Mineral Nutrition of Higher Plants. P.1-889. Academic Press, New York.

[21] Martens, D. C. and Westermann, D. T. 1991. Fertilizer applications for correcting micronutrient deficiencies. p. 549-592. In: Micronutrients in agriculture. $2^{\text {nd }}$ ed. Soil Sci. Soc. of Agron. SSSA Book Series no: 4, Madison.

[22] Navrot, J. and Ravikovitch, S. 1968. Zinc availability in calcareous soils. II: Relation 
between available zinc and response to zinc fertilization. Soil Sci. 105 : 184-189.

[23] Norvell, W. A. 1984. Comparison of chelating agents as extractants for metals in diverse soil materials. Soil Sci. Soc. Am. J. 48: 1285-1292.

[24] Olson, R.V. 1948. Iron solubility in soils as affected by $\mathrm{pH}$ and free iron oxide content. Soil Sci. Soc. Amer. Proc. 12 : 153-157.

[25] Özgüven, N. and Katkat, A. V. 2001. The plant available zinc status of the soils of Bursa and the methods used for the determination of zinc contents of these soils. Journal of Faculty of Agriculture, Uludad University, 15, 177-190, (in Turkish).

[26] Pseiter, B. J. and Robinson, J. B. 1986. Plant analyses, Inc. Melbourne, Sydney.

[27] Saglam, M. T.; Tok, H. H.; Adiloglu, A.; Demirkýran, A. R. and Bellitürk, K. 1997. An investigation on available $\mathrm{Fe}, \mathrm{Cu}, \mathrm{Zn}$ and $\mathrm{Mn}$ contents of soil samples collected from Thrace Region. Proceedings of Thrace I. Soil and Fertilizer Symposium, 20-22 October, Tekirdag, pp.248-252, (in Turkish).

[28] Singh, R. S.; Singh, R. P.; Rai, R. K. and Agrawal, H. P. 1994. Relationship between soil test methods and uptake of copper and zinc by grasses on polluted soils. Comm. in Soil Sci. and Plant Anal.25: 9/ 10, 1313-1320.

[29] Soltanpur, P. N. 1991. Determination of nutrient availability and elementel toxicity by AB- DTPA soil test and ICPS, p.165-190. In B. A. Stewart (ed.), Adv. Soil Sci. Vol: 16, Springer- Verlag, New York

[30] Stewart, J.A. and Berger, K.C. 1965. Estimation of available soil zinc using magnesium chloride as extraction. Soil Sci., 100 (4), 244- 250.

[31] Sumner, M. E. and Miller, W. P., 1996. Cation exchange capacity and exchange coefficients. p: 1201-1229. In D: L. Sparks et al. (ed.). Methods of soil analysis, Part 3, Chemical methods, SSSA Book series no: 5, SSSA and ASA, Madison,

[32] Thomas, G. W. 1996., Soil pH and soil acidity. p: 475-490. In D: L. Sparks et al. (ed.). Methods of soil analysis, Part 3, Chemical methods, SSSA Book series no: 5, SSSA and ASA, Madison.

[33] Trierweiler, F.J. and Lindsay, W.L. 1969. EDTA- Ammonium carbonate soil test for zinc. Soil Sci. Amer. Proc. 33 : 49-54.

[34] Turan, C.; Çelebi, G.; Yalçýn, R.; Kacar, B. and Taban, S. 1989. Trace element status in Antalya Coastal Region Soils and the comparison of some chemical extraction methods for plant available $\mathrm{Fe}, \mathrm{Mn}, \mathrm{Zn}$ and $\mathrm{Cu}$ in these soils. Journal of Doða, 20 (36): 12941307, (in Turkish).

[35] Wear, J. I. and Evans, C. E. 1968. Relationship of zinc uptake by corn and sorghum to soil zinc measured by three extractions. Soil Sci. Soc. Amer. Proc. 32 : $543-546$.

[36] Yýldýz, N. and Özkutlu, F. 1997. Evaluation of chemical methods used to determine plant available soil nitrogen of some Ordu Soils. Journal of Faculty of Agriculture, Atatürk University, 28 (4): 565-575, (in Turkish).

[37] Yurtsever, N. 1984. Experimental Statistical Methods, General Directorate of Rural Service Publ. No: 121, p.624, (in Turkish).

Aydýnn Adiloglu, a adiloglu@hotmail.com,

U. Tekirdag Agricultural Faculty Soil Science Dept. 59030-Tekirdag / TURKEY

Tel: 90282 2931442, Fax: 902822931454 